\title{
In vitro free radical scavenging activity of hydroethanolic leaf extract of Ixora macrothyrsa (Tejism. and Binn.)
}

\author{
G. Suruthi Saraswathi, D. Victor Arokia Doss \\ Department of Biochemistry, PSG College of Arts and Science, Coimbatore, Tamil Nadu, India
}

\begin{abstract}
Objective: The present study aimed to evaluate the free radical scavenging activity of hydroethanolic leaf extract of Ixora macrothyrsa (Tejism. and Binn.). Materials and Methods: The hydroethanolic leaf extract of I. macrothyrsa was analyzed for free radical scavenging assay, namely 1-diphenyl-2-picrylhydrazyl (DPPH), hydroxyl radical, hydrogen peroxide $\left(\mathrm{H}_{2} \mathrm{O}_{2}\right)$, and nitric oxide (NO) scavenging activity. Results: The hydroethanolic leaf extract of I. macrothyrsa was shown to scavenge DPPH, hydroxyl, $\mathrm{H}_{2} \mathrm{O}_{2}$, and $\mathrm{NO}$ radicals dose dependently with an $\mathrm{IC}_{50}$ value of $405.36,306.57,351.46$, and $612.76 \mu \mathrm{g} / \mathrm{mL}$, respectively. Conclusion: The results suggest that I. macrothyrsa has a promising antioxidant activity and could serve as a potential source of natural antioxidant.
\end{abstract}

Key words: Antioxidants, hydroethanolic leaf extract, Ixora macrothyrsa, scavenging activity

\section{INTRODUCTION}

$\mathrm{F}$ ree radicals are molecules having an unpaired electron in the outer orbit which are unstable and very reactive. ${ }^{[1]}$ These are electrically charged entities that attack the cells and damage the nucleic acids, proteins, and enzymes present in the body. ${ }^{[2]}$ In living systems, free radicals are produced through the oxidative process. Antioxidant defense mechanism involves in the elimination of free radicals which cause the oxidative stress. ${ }^{[3]}$ Natural antioxidants from plants and their chemical constituents are very effective in the prevention of destructive processes caused by oxidative stress. ${ }^{[4]}$ Extraction of antioxidants from medicinal plants plays a major role in the promotion and application of functional foods, pharmaceuticals, and food additives. ${ }^{[5]}$ There are about 400 species of Ixora, of which 28 are cultivated widely. ${ }^{[6]}$ The flowers of various species of Ixora are used in the treatment of dysmenorrhea, wound healing, and catarrhal bronchitis. ${ }^{[7]}$ Furthermore, the plant Ixora has antiasthmatic, anti-inflammatory, antitumor, and antiviral activities. ${ }^{[8]}$

\section{MATERIALS AND METHODS}

\section{Plant Collection and Authentication}

Ixora macrothyrsa (Tejism. and Binn.) was collected from Coimbatore, Tamil Nadu. The plant was identified and certified by the taxonomist, Botanical Survey of India (BSI) (BSI/SRC/5/23/2013-14/Tech/1417), Coimbatore, Tamil Nadu, India.

\section{Preparation of Hydroethanolic Extract}

The leaves of I. macrothyrsa were soaked in $50 \%$ ethanol and macerated for 3 days in cold with occasional stirring. The suspension was filtered, and the filtrate was taken in a roundbottomed glass flask. The sample was then evaporated to dryness at a low temperature in a rotary evaporator. Finally, dark brown-colored crystals obtained were used for free radical scavenging assay.

\section{Free Radical Scavenging Assay}

\section{1-Diphenyl-2-picrylhydrazyl (DPPH) radical scavenging assay ${ }^{[9]}$}

The ethanolic solution of $0.5 \mathrm{~mL}$ of DPPH was added to $1 \mathrm{~mL}$ of the different concentrations $(100-500 \mu \mathrm{g} / \mathrm{mL})$ of samples. The reaction mixture was allowed to stand at the room temperature

\section{Address for correspondence:}

Dr. D. Victor Arokia Doss, Department of Biochemistry, PSG College of Arts and Science, Coimbatore, Tamil

Nadu, India. E-mail: ragasuru@gmail.com

Received: $27-07-2018$

Revised: 26-10-2018

Accepted: 08-11-2018 
for 30 min. Ethanol served as the blank. After the incubation period, the absorbance was measured at $518 \mathrm{~nm}$ and converted into percentage radical scavenging activity as follows:

$$
\begin{gathered}
\text { Absorbance (control) }- \\
\text { Scavenging activity } \%=\frac{\text { Absorbance }(\text { sample })}{\text { Absorbance }(\text { control })} \times 100
\end{gathered}
$$

\section{Hydroxyl radical scavenging assay ${ }^{[10]}$}

The reaction mixture contained $0.1 \mathrm{~mL}$ of buffer, $0.5 \mathrm{~mL}$ of various concentration $(100-500 \mu \mathrm{g} / \mathrm{mL})$ of plant extract, $0.2 \mathrm{~mL}$ of ferric chloride, $0.1 \mathrm{~mL}$ of ascorbic acid, $0.1 \mathrm{~mL}$ of ethylenediaminetetraacetic acid, $0.1 \mathrm{~mL}$ of hydrogen peroxide $\left(\mathrm{H}_{2} \mathrm{O}_{2}\right)$, and $0.2 \mathrm{~mL}$ of 2-deoxyribose. The contents were mixed thoroughly and incubated at the room temperature for $1 \mathrm{~h}$. Then, $1.0 \mathrm{~mL}$ of thiobarbituric acid and $1.0 \mathrm{~mL}$ of trichloroacetic acid were added. All the tubes were kept in a boiling water bath for $30 \mathrm{~min}$. The absorbance of the supernatant was read in a spectrophotometer at $535 \mathrm{~nm}$.

\section{$\mathrm{H}_{2} \mathrm{O}_{2}$ scavenging activity ${ }^{[11]}$}

A solution of $\mathrm{H}_{2} \mathrm{O}_{2}(20 \mathrm{mM})$ was prepared in phosphate buffer saline ( $\mathrm{pH} 7.4) .1 \mathrm{~mL}$ of different concentrations of plant extract and standard ascorbic acid solution $(100-500 \mu \mathrm{g} / \mathrm{mL})$ was added to $2 \mathrm{~mL}$ of $\mathrm{H}_{2} \mathrm{O}_{2}$ solution. The tubes which were incubated at room temperature for $10 \mathrm{~min}$ at an absorbance of $\mathrm{H}_{2} \mathrm{O}_{2}$ was measured at $230 \mathrm{~nm}$ against a blank solution containing phosphate buffer without $\mathrm{H}_{2} \mathrm{O}_{2}$.

\section{Nitric oxide (NO) radical scavenging activity ${ }^{[12]}$}

The reaction mixture $(3.0 \mathrm{~mL})$ contained $2 \mathrm{~mL}$ of sodium nitroprusside $(10 \mathrm{mM}), 0.5 \mathrm{~mL}$ of phosphatebuffersaline $(1 \mathrm{M})$, and $0.5 \mathrm{~mL}$ of different concentrations $(100-500 \mu \mathrm{g} / \mathrm{mL})$ of plant extract which was incubated at $25^{\circ} \mathrm{C}$ for $2 \mathrm{~h} 30 \mathrm{~min}$. After the incubation process, $0.5 \mathrm{~mL}$ of the Griess reagent was added. In control, an equal volume of buffer was added without the test compound. The absorbance of the chromophore formed during diazotization coupling with naphthyl ethylenediamine was read at $540 \mathrm{~nm}$.

\section{RESULTS AND DISCUSSION}

\section{DPPH Radical Scavenging Assay}

The hydroethanolic leaf extract of I. macrothyrsa produced dosedependent radical scavenging activities as depicted in Figure 1. The percentage of DPPH radical inhibition of the hydroethanolic leaf extract of I. macrothyrsa and standard ascorbic acid was found to be $58 \%$ and $78 \%$ at $500 \mu \mathrm{g} / \mathrm{mL}$ concentration, respectively. $\mathrm{The} \mathrm{IC}_{50}$ value of the leaf extract and ascorbic acid was found to be 405.36 and $281.40 \mu \mathrm{g} / \mathrm{mL}$, respectively. The effect of antioxidants on DPPH radical was due to their ability of donating hydrogen atoms to the free radicals and reducing it to non-reactive species. The purple-colored DPPH radical was reduced to yellow by the action of antioxidants. ${ }^{[13]}$

\section{Hydroxyl Radical Scavenging Assay}

The percentage inhibition of the hydroethanolic leaf extract of I. macrothyrsa and standard ascorbic acid was found to be $72 \%$ and $88 \%$ at $500 \mu \mathrm{g} / \mathrm{mL}$ concentration, respectively, as shown in Figure 2. The $\mathrm{IC}_{50}$ value of the leaf extract and ascorbic acid was found to be 306.57 and $249.95 \mu \mathrm{g} / \mathrm{mL}$, respectively. Hydroxyl radicals are the important oxygen species causing lipid peroxidation and cause severe damage to the biological membrane. ${ }^{[14]}$ Hydroxyl radicals also damage the DNA, lipids, and proteins. ${ }^{[15]}$

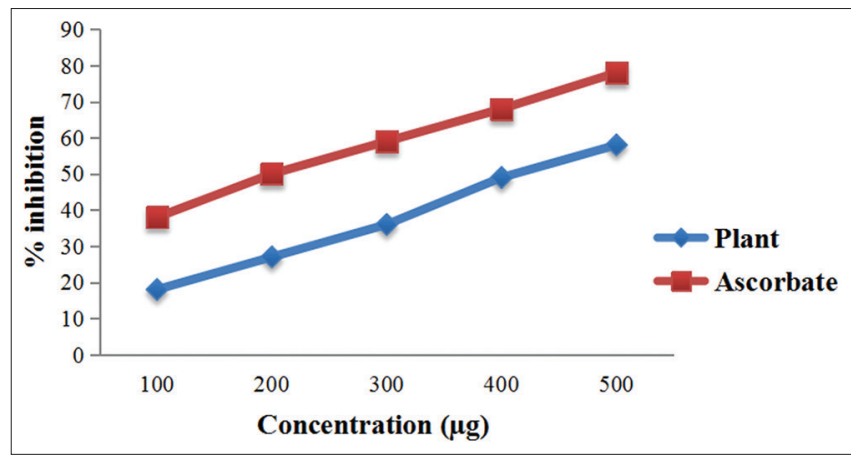

Figure 1: 1-Diphenyl-2-picrylhydrazyl radical scavenging activity of plant and ascorbate

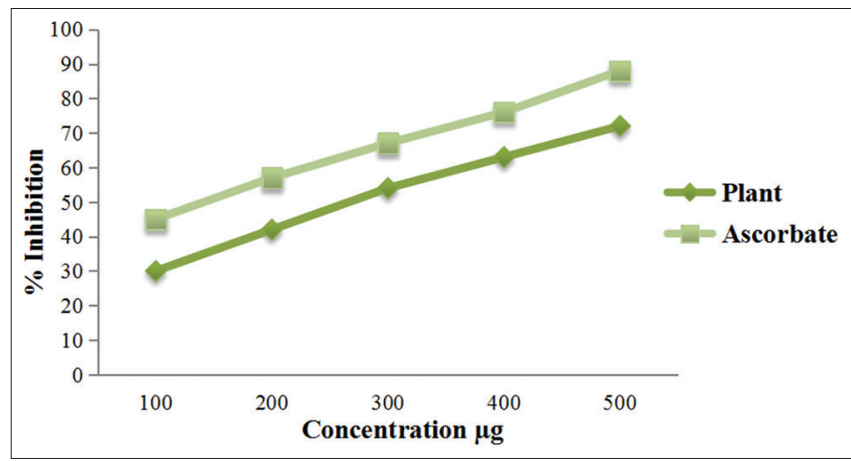

Figure 2: Hydroxyl radical scavenging activity of plant and ascorbate

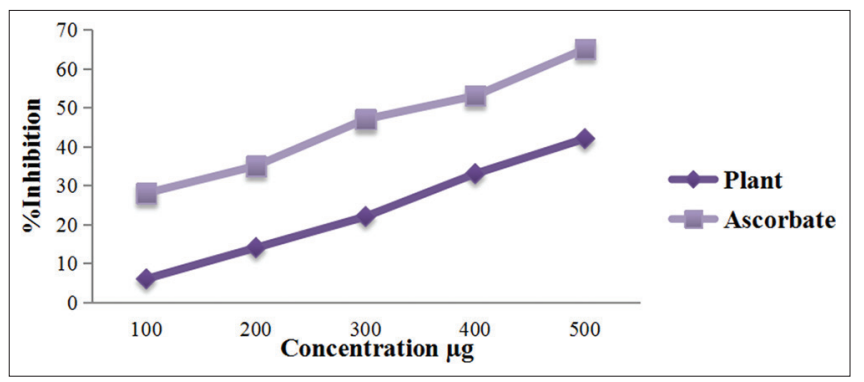

Figure 3: Nitric oxide radical scavenging activity of plant and ascorbate 


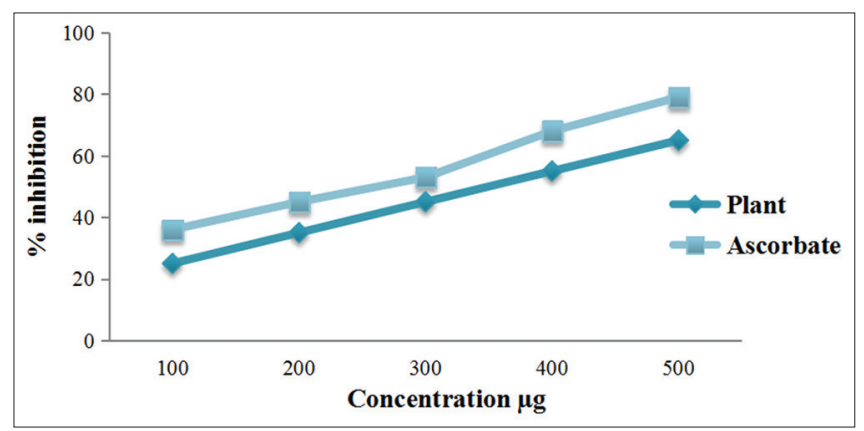

Figure 4: Hydrogen peroxide radical scavenging activity of plant and ascorbate

\section{$\mathrm{H}_{2} \mathrm{O}_{2}$ Scavenging Activity}

Figure 3 depicts the percentage of hydroxyl radical inhibition by the hydroethanolic leaf extract of I. macrothyrsa and ascorbic acid in a dose-dependent manner with maximum inhibition of $65 \%$ and $79 \%$ at $500 \mu \mathrm{g} / \mathrm{mL}$ concentration as shown in Figure 4. $\mathrm{IC}_{50}$ value of the leaf extract and ascorbic acid was found to be 351.46 and $286.13 \mu \mathrm{g} / \mathrm{mL}$, respectively. $\mathrm{H}_{2} \mathrm{O}_{2}$ occurs in the air, water, human body, plants, and microorganisms at very low concentration. ${ }^{[16]}$ $\mathrm{H}_{2} \mathrm{O}_{2}$ is decomposed to oxygen and water, thereby producing hydroxyl radicals $(. \mathrm{OH})$. Hydroxyl radicals activate the lipid peroxidation process and cause severe damage to the DNA. ${ }^{[17]}$

\section{NO Radical Scavenging Activity}

$\mathrm{NO}$ is a free radical produced in mammalian cells and is involved in the regulation of various physiological processes. ${ }^{[18]}$ The percentage of NO radical inhibition by hydroethanolic leaf extract of $I$. macrothyrsa was found to be $42 \%$ which was comparable to the standard ascorbic acid $65 \%$ at $500 \mu \mathrm{g} / \mathrm{mL}$ concentration as depicted in Figure $3 . \mathrm{IC}_{50}$ value of the leaf extract and ascorbic acid was found to be 612.76 and $350.1 \mu \mathrm{g} /$ $\mathrm{mL}$, respectively. $\mathrm{NO}$ is involved in the process of relaxation of smooth muscle, neuronal signaling, retardation of platelet aggregation, and maintenance of cell-mediated toxicity. ${ }^{[19]}$

\section{CONCLUSION}

The results obtained in the present investigation indicated that the hydroethanolic leaf extract of I. macrothyrsa exhibited potent free radical scavenging activity. Thus, I. macrothyrsa could serve as potential sources of natural antioxidants against oxidative stress, which participate in neurodegenerative diseases and biological damage in living tissues.

\section{ACKNOWLEDGMENT}

Authors wish to acknowledge the Department of Biochemistry, PSG College of Arts and Science, Tamil Nadu, India, for providing the necessary laboratory facilities.

\section{REFERENCES}

1. Gilbert DL. Fifty years of radical ideas. Ann N Y Acad Sci 2000;899:1.

2. Aher VD, Wahi AK, Pawdey AM, Sonawane A. Antioxidants as immunomodulator: An expanding research avenue. Int J Curr Pharm Res 2011;3:810.

3. Halliwell B. Free radicals, antioxidants and human disease: Curiosity, cause or consequence? Lancet 1995;344:721-4.

4. Zengin G, Cakmak YS, Guler GO, Aktumsek A. Antioxidant properties of methanolic extract and fatty acid composition of Centaurea urvellei DC subsp. Hayekiana wagneitz. Rec Nat Prod 2011;5:123-32.

5. Xu DP, Li Y, Meng X, Zhou T, Zhou Y, Zheng J, et al. Natural antioxidants in foods and medicinal plants: Extraction, assessment and resources. Int J Mol Sci 2017;18:1-32.

6. Elumalai A, Eswaraiah C, Venkatesh Y, Burle SK, Narenda, C. Phytochemical and pharmacological profile of Ixora coccinea Linn. Int J Pharm Life Sci 2012;3:1563-7.

7. Sankaranarayanan S, Bama P. Ethnobotanical study of medicinal plants used by traditional users in Villupuram district of Tamil Nadu, India. J Med Plant Res 2010;4:1089-101.

8. Saha MR, Alam A, Akter R, Jahangir R. An in vitro free radical scavenging activity of Ixora coccinea $\mathrm{L}$. Bangladesh J Pharmacol 2008;3:90-6.

9. Khalaf NA, Shakya AK, Al-othman A, El-agbar Z, Farah H. Antioxidant activity of some common plant. Turk J Biol 2008;32:51-5.

10. Halliwell B, Gutteridge JM, Aruoma OI. The deoxyribose method: A simple 'test-tube' assay for determination of rate constants for reactions of hydroxyl radicals. Anal Biochem 1987;165:215-9.

11. Sroks Z, Cisowski W. Hydrogen peroxide scavenging, antioxidant and antiradical activity of some phenolic acids. Food Chem Toxicol 2003;41:7538.

12. Sreejayan N, Rao MN. Nitric oxide scavenging by curcuminoids. J Pharm Pharmacol 1997;49:105-7.

13. Wang $\mathrm{H}$, Gao XD, Zhou GC, Cai L, Yao WB. In vitro and in vivo antioxidant activity of aqueous extract from Choerospondias axillaris fruit. Food Chem 2008;106:888-95.

14. Aurand LW, Boone NH, Giddings GG. Superoxide and singlet oxygen in milk lipid peroxidation. J Diary Sci 1977;60:363-9.

15. Srikanth G, Babu SM, Kavitha CH, Rao ME, VijaykumarN, Pradeep CH. Studies on in vitro antioxidant activities of Carica papaya aqueous leaf extract. Res J Pharm Biol Chem Sci 2010;1:59-65.

16. Gulcin I, Berashvili D, Gepdiremen A. Antiradical and antioxidant activity of total anthocyanins from Perilla pankinensis Decne. J Ethanopharmacol 2005;101:287-93.

17. Sahreen S, Khan MR, Khan RA. Phenolic compounds and antioxidant activities of Rumex hastatus D. Don. Leaves. J Med Plants Res 2011;5:2755-65.

18. Nalini P, Durairaj B. In vitro free radical scavenging 
potential of hydroethanolic extract in the leaves of Annona muricata. Int J Green Pharm 2018;12:280-3.

19. Hangerman AE, Riedl KM, Jones GA, Sovik KN, Richard NT, Hartzfeld PW. High molecular weight polyphenolics (tannins) as biological antioxidants. J Agric Food Chem 1998;46:1887-92.

Source of Support: Nil. Conflict of Interest: None declared. 